\title{
Imunidade dos Livros Eletrônicos: uma análise dos (des)caminhos do STF sob a perspectiva dos direitos fundamentais à cultura, à liberdade de expressão e ao meio ambiente ecologicamente equilibrado
}

\author{
Maria Lírida Calou de Araújo e Mendonça ${ }^{1}$ \\ Germana Parente Neiva Belchior ${ }^{2}$ \\ Fernanda Mara de Oliveira Macedo Carneiro Pacobahyba ${ }^{3}$
}

Resumo: O objetivo geral deste artigo é investigar os desafios e as perspectivas do STF no que se refere à temática da imunidade dos livros eletrônicos, tendo como foco os direitos fundamentais ao meio ambiente sadio, à cultura e à liberdade de expressão. A metodologia utilizada é bibliográfica, teórica, descritiva, exploratória, jurisprudencial e dialética com predominância indutiva. A questão da imunidade

\begin{abstract}
The main purpose of this paper is to examine the challenges the Federal Supreme Court of Brazil faces regarding the tax immunity of e-books, focusing on the fundamental rights to an ecologically balanced environment, to culture and to freedom of expression. Methodology used is bibliographical, theoretical, descriptive, dialetic and case law-based, being also mainly inductive. The issue of the tax immunity of e-books must
\end{abstract}

1 Pós-Doutora em Direito pela Universidade Federal de Santa Catarina (UFSC). Doutora em Direito pela Universidade Federal de Pernambuco (UFPE). Mestre em Direito Constitucional pela Universidade Federal do Ceará (UFC). Professora do Programa de Pós-Graduação em Direito da Universidade de Fortaleza (UNIFOR).E-mail: lirida@ unifor.br.

2 Doutoranda em Direito pela Universidade Federal de Santa Catarina (UFSC). Mestre em Direito Constitucional pela Universidade Federal do Ceará (UFC). Professora universitária. Analista Jurídica da Secretaria da Fazenda do Estado do Ceará. E-mail: germana_belchior@yahoo.com.br.

3 Mestre em Direito Constitucional pela Universidade de Fortaleza (UNIFOR). Professora universitária. Analista Jurídica da Secretaria da Fazenda do Estado do Ceará. E-mail: pacmara@yahoo.com.br.

Recebido em: 08/02/2011.

Revisado em: 04/04/2011.

Aprovado em: 10/06/2011. 
dos livros eletrônicos deve ser analisada sob o atual do contexto do pós-positivismo e do neoconstitucionalismo. Diferentemente da interpretação restritiva e equivocada realizada pelo $\mathrm{STF}$, entende-se que o conceito jurídico de livro deve ser o mais amplo possível, tendo em mente uma interpretação teleológica e sistemática, o que faz legítima e necessária uma mutação constitucional do artigo 150, inciso IV, alínea "d", da Carta Magna. Conclui-se, portanto, que a extensão da imunidade aos livros eletrônicos contribui para a proteção do direito ao ambiente sadio, bem como para a propagação da cultura e da liberdade de expressão. Espera-se, por fim, um entendimento desta Egrégia Corte favorável à cultura brasileira e ao acesso mais consciente ecologicamente aos meios de informação.

Palavras-chave: Garantias Fundamentais. Contribuinte. Imunidade. Livros Eletrônicos. Supremo Tribunal Federal. be examined taking into account that postpositivism and neoconstitutionalism are basic references in modern Law. Different to the limited and misguided interpretation used by the Federal Supreme Court of Brazil, and based upon systematic and teleological interpretation methods, the juridical notion of book should be the widest possible, rendering legitimate and necessary a constitutional mutation, which would affect Section 150, IV, "d", of Brazilian Federal Constitution. The author concludes that extending tax immunity to e-books contributes to the protection of a healthier environment, as well as to the diffusion of culture and to the promotion of freedom of expression. Finally, the author expects that the Federal Supreme Court adopts a new position, favourable to Brazilian culture and to a more ecologically correct access to information.

Keywords: Fundamental rights. Taxpayer. Tax immunity. E-books. Federal Supreme Court of Brazil.

\section{Introdução}

A atual Constituição da República Federativa do Brasil, fruto de um longo processo de tentativa de redemocratização, trouxe um rol extenso de direitos e garantias fundamentais que, em sua maioria, são violados pelo próprio Estado.

Assim, tendo como um dos poderes inerentes a esse Estado a tributação, atividade-meio concebida para que os fins pretendidos pelo órgão estatal possam ser alcançados, a relação de invasão do patrimônio dos contribuintes, muitas vezes, não se dá de forma asséptica e respeitosa.

O objetivo geral deste artigo é investigar os desafios e as perspectivas do STF no que se refere à temática da imunidade dos livros eletrônicos, tendo como foco os direitos fundamentais ao meio ambiente sadio, à cultura e à liberdade de expressão. A metodologia utilizada é bibliográfica, teórica, descritiva, exploratória, jurisprudencial e dialética com predominância indutiva. 
Inicialmente, discute-se o alcance dos direitos e garantias fundamentais dos contribuintes para então analisar a imunidade prevista no artigo 150, inciso VI, alínea “d”, CF/88, que abrange "livros, jornais, periódicos e o papel destinado a sua impressão".

Em seguida, passa-se a discorrer sobre o atual contexto do neoconstitucionalismo e do pós-positivismo com vistas a perceber a importância da Hermenêutica Constitucional para o preenchimento de um conceito jurídico de livro.

Merece, ainda, reflexão a extensão da imunidade dos livros para a sua forma eletrônica, no sentido de verificar se tal situação jurídica contribuiria ou não para a proteção do meio ambiente ecologicamente equilibrado, bem como para a propagação da cultura e da liberdade de expressão.

Por fim, intenta-se apontar os possíveis rumos que o STF pode tomar em relação à temática, tendo em vista a repercussão geral concedida pelo Ministro Marco Aurélio, quando do julgamento do RE 295.676/RJ, sendo um importante marco para a disseminação de uma cultura sustentável.

\section{A Imunidade Tributária como Garantia Fundamental do Con- tribuinte}

Em um primeiro momento, vale fazer uma breve incursão sobre o alcance dos direitos e garantias fundamentais, notadamente quando se fala em proteção dos contribuintes.

De há muito se convencionou denominar por direitos fundamentais aqueles positivados na Constituição, em contraposição aos direitos humanos, que teriam um caráter mais universalizante, não necessariamente internalizados na legislação de cada Estado.

A expressão "direitos fundamentais" deve ser aplicada, segundo Sarlet, aos direitos do homem, reconhecidos e positivados nas constituições. Para o citado autor:

Não há como olvidar, neste contexto, que a opção do Constituinte, ao erigir certa matéria à categoria de direito fundamental, se baseia 
na efetiva importância que aquela possui para a comunidade em determinado momento histórico, circunstância esta indispensável para que determinada posição jurídica possa ser identificada como fundamental. (SARLET, 2007, p. 96)

Notadamente, é com base nos valores considerados importantes a uma dada sociedade que o constituinte, de forma intuitiva e racional, seleciona quais bens terão proteção na Lei Maior. Os direitos fundamentais são aqueles que, ao incorporar os valores mais importantes de determinada sociedade, protegem os bens mais caros a ela.

Salienta-se, ademais, que os direitos fundamentais não são criados pela Constituição, e sim reconhecidos por esta, sendo originários em meio à sociedade, por meio da indução. É por isso que se defende o caráter vinculativo dos direitos fundamentais em relação ao Executivo, ao Legislativo e ao Judiciário. Não se confundem, entretanto, com os direitos humanos, típicos de normas de cunho internacional, carecendo, em regra, mas não sempre, de eficácia jurídica perante um dado ordenamento jurídico.

Com isso, pode-se dizer que os direitos e as garantias fundamentais são aqueles essenciais para que o homem possa ter uma existência com dignidade, gozando da liberdade necessária para se afirmar enquanto ser humano, no âmbito interno de um ordenamento jurídico.

Corresponde às necessidades de desenvolvimento moral, espiritual, intelectual, em que a evolução possa vir acompanhada do desenvolvimento de toda a sociedade, quando o homem se reconstrói e incorpora novos anseios até então desconhecidos.

No Brasil, especialmente após a Constituição de 1988, tais direitos e garantias passam a ter uma projeção nunca dantes vista. Previstos no Título II da CF/88, compõem um rol que não se restringe a esse espaço bem demarcado do texto, por expressa determinação contida no artigo $5^{\circ}, \S 2^{\circ}$, da Carta Magna. ${ }^{4}$

\footnotetext{
4 "§ $2^{\circ}$ - Os direitos e garantias expressos nesta Constituição não excluem outros decorrentes do regime e dos princípios por ela adotados, ou dos tratados internacionais em que a República Federativa do Brasil seja parte." (destacado)
} 
Impõe destacar a ressalva já feita por Canotilho (1999, p. 823) acerca das estruturas de garantia e controle:

O Estado constitucional democrático ficaria incompleto e enfraquecido se não assegurasse um mínimo de garantias e de sanções: garantias da observância, estabilidade e preservação das normas constitucionais; sanções contra actos dos órgãos de soberania e dos outros poderes públicos não conformes com a constituição. A ideia de protecção, defesa, tutela ou garantia da ordem constitucional tem como antecendente a ideia de defesa do Estado, que, num sentido amplo e global, se pode definir como o complexo de institutos, garantias e medidas destinadas a defender e proteger, interna e externamente, a existência jurídica e fáctica do Estado (defesa do território, defesa da independência, defesa das instituições). (grifo no original)

Como se vê, direitos não se confundem com garantias, na medida em que estas são instrumentos utilizados para que os direitos possam ser assegurados. Quanto se trata de direitos e garantias fundamentais, Marques de Lima (2002) explica que de nada adiantaria um ordenamento jurídico repleto de direitos se não existissem mecanismos para sua proteção e concretização. Dessa forma, faz-se mister garantias fundamentais que objetivem limitar a atividade do Poder Público com relação a direitos específicos.

No Direito Tributário, notadamente camufladas sob a expressão "Das limitações ao poder de tributar [...]", a partir do artigo $150^{5}$ da Constituição Federal de 1988, o que se percebe é um extenso rol de limitações

5 “Art. 150. Sem prejuízo de outras garantias asseguradas ao contribuinte, é vedado à União, aos Estados, ao Distrito Federal e aos Municípios:

I - exigir ou aumentar tributo sem lei que o estabeleça;

II - instituir tratamento desigual entre contribuintes que se encontrem em situação equivalente, proibida qualquer distinção em razão de ocupação profissional ou função por eles exercida, independentemente da denominação jurídica dos rendimentos, títulos ou direitos;

III - cobrar tributos:

a) em relação a fatos geradores ocorridos antes do início da vigência da lei que os houver instituído ou aumentado; 
ao exercício, pelo próprio Estado, do seu poder de tributar. Trata-se das imunidades tributárias, cuja natureza jurídica se revela ora como direito, ora como garantia, a depender do caso concreto. ${ }^{6}$

As imunidades, na qualidade de garantia, uma vez opostas ao Estado, têm como destinatário primeiro o próprio contribuinte, seja este pessoa física ou jurídica, ente personalizado ou despersonalizado, capaz ou incapaz, visto que a tributação não faz qualquer distinção, com exceção das limitações previstas na Lei Maior.

Sobre o tema, Carrazza (2008, p. 705) ilustra que as imunidades integram o processo de delimitação do campo tributário. Seriam, no entender do autor, “[...] normas negativas $[\ldots]$ ”, pois estabelecem limites à atuação do legislador ao editar normas tributárias:

A imunidade tributária é um fenômeno de natureza constitucional. As normas constitucionais que, direta ou indiretamente, tratam do assunto fixam, por assim dizer, a incompetência das entidades tributantes para onerar, com exações, certas pessoas, seja em função de sua natureza jurídica, seja porque coligadas a determinados fatos, bens ou situações. (grifo no original)

b) no mesmo exercício financeiro em que haja sido publicada a lei que os instituiu ou aumentou;

c) antes de decorridos noventa dias da data em que haja sido publicada a lei que os instituiu ou aumentou, observado o disposto na alínea b;

IV - utilizar tributo com efeito de confisco;

$\mathrm{V}$ - estabelecer limitações ao tráfego de pessoas ou bens, por meio de tributos interestaduais ou intermunicipais, ressalvada a cobrança de pedágio pela utilização de vias conservadas pelo Poder Público;

VI - instituir impostos sobre:

a) patrimônio, renda ou serviços, uns dos outros;

b) templos de qualquer culto;

c) patrimônio, renda ou serviços dos partidos políticos, inclusive suas fundações, das entidades sindicais dos trabalhadores, das instituições de educação e de assistência social, sem fins lucrativos, atendidos os requisitos da lei;

d) livros, jornais, periódicos e o papel destinado a sua impressão." (destacado)

6 Apesar de a temática ser relevante, não será aqui aprofundada, sob pena de desvirtuar o foco deste trabalho científico. 
Para Machado (2002, p. 94), a imunidade não se enquadra como instituto de Direito Tributário. O autor cearense defende que esta "[...] consiste, antes de tudo, em instrumento de preservação dos valores constitucionais contra a possível ação do Estado".

Importa destacar, ainda, que o rol das garantias fundamentais do contribuinte não é taxativo, mormente quando o próprio texto constitucional expõe na parte inicial do caput do artigo 150 "[...] sem prejuízo de outras garantias asseguradas ao contribuinte". Não obstante expressa previsão constitucional, nunca é demais lembrar que a Constituição deve ser interpretada de forma una e sistêmica, com vistas a atender a teleologia do constituinte.

Hesse (1991, p. 21), propagador da força normativa da Constituição, expõe que a Carta Magna “[...] não deve assentar-se numa estrutura unilateral, se quiser preservar a sua força normativa num mundo em processo de permanente mudança político-social". (grifo no original). Para tanto, deve-se manter una, coerente, sofrendo os embates com a Constituição real, mas mantendo a sua integridade.

Sob o mesmo espírito, Mendes (2009, p. 135) ressalta que, a partir $\S 2^{\circ}$ do artigo $5^{\circ}, \mathrm{CF} / 88$,

[...] as normas constitucionais devem ser vistas não como normas isoladas, mas como preceitos integrados num sistema unitário de regras e princípios, que é instituído na e pela própria Constituição.

Destaca, ainda, o autor que

[...] a Constituição só pode ser compreendida e interpretada corretamente se nós a entendermos como unidade, do que resulta, por outro lado, que em nenhuma hipótese devemos separar uma norma do conjunto em que ela integra, até porque - relembre-se o círculo hermenêutico - o sentido da parte e o sentido do todo são interdependentes. (MENDES, 2009, p. 135)

Notadamente, é imperiosa a unidade da Constituição como o princípio que permite uma leitura ampla e irrestrita do Sistema Tributário Na- 
cional à luz dos direitos e das garantias fundamentais, em especial, no que concerne às imunidades.

\section{Considerações Gerais da Imunidade Tributária dos Livros}

Na segunda parte deste trabalho, será analisada a imunidade prevista no artigo 150, inciso VI, alínea "d", $\mathrm{CF} / 88$, que abrange "[...] livros, jornais, periódicos e o papel destinado a sua impressão".

Ao seguir, no raciocínio empreendido por Baleeiro (2007) sobre a historicidade dessa imunidade, verifica-se que a Constituição de 1946 foi deveras relevante por ser a primeira a distribuir as competências tributárias entre os entes políticos, a exemplo do que ocorre com a atual Carta. Assim, nos termos do artigo 31 da Constituição de 1946:

Art. 31 - A União, aos Estados, ao Distrito Federal e aos Municípios é vedado: $[. .$.

$V$ - lançar impostos sobre:

$[\ldots]$

c) papel destinado exclusivamente à impressão de jornais, periódicos e livros. (destacado)

Logicamente, para a sociedade da época, em que não se cogitava da existência de qualquer forma de manifestação do pensamento escrito que não fosse pelo papel, tal imunidade estava perfeitamente estruturada ao se preocupar apenas com ele.

Em seguida, pode-se visualizar que a Constituição de 1967 amplia o entendimento anterior:

Art. 20 - É vedado à União, aos Estados, ao Distrito Federal e aos Municípios: [...]

III - criar imposto sobre:

[...]

d) o livro, os jornais e os periódicos, assim como o papel destinado à sua impressão. (destacado) 
A partir de então, passa-se a ter uma previsão semelhante à atual, implicando em uma mudança sensível da imunidade prevista originariamente e aquela agora disposta. Entretanto, essa alteração, na prática, não foi sentida, visto que se continuava com o mesmo padrão de publicação dos livros.

A Emenda Constitucional n. 1/69 mantém o texto acima, alterando-se apenas a numeração do artigo:

Art. 19. É vedado à União, aos Estados, ao Distrito Federal e aos Municípios:

$[\ldots]$

III - instituir impôsto sôbre:

$[\ldots]$

d) o livro, o jornal e os periódicos, assim como o papel destinado à sua impressão. (destacado)

A Constituição Federal de 1988 mantém praticamente idêntica a redação acima, como se verifica no artigo 150, inciso VI, alínea “d”. Ocorre que uma mudança substancial na sociedade, propiciada pela evolução dos meios tecnológicos e do fortalecimento da crise ambiental, forçará uma leitura mais abrangente dessa garantia fundamental, em consonância com o entendimento amplo que deve ser feito dos direitos e garantias fundamentais.

Ao analisar a abrangência desta imunidade sob a ótica das referidas alterações, Baleeiro (2007, p. 148) afirma que “[...] este ainda é o objetivo constitucional de proteção à educação, à cultura e à liberdade de comunicação do pensamento".

Como se observa, a imunidade em tela é objetiva, uma vez que é conferida em função de um bem material protegido, destacando-o da competência tributária e, na sequência, beneficiando as pessoas que realizem operações com tais bens (WANDERLEY, 2010).

Nessa esteira de raciocínio, manifesta-se Mizabel Derzi, em citação feita por Baleeiro (2007, p. 151): 
A imunidade tributária, constitucionalmente assegurada aos livros, jornais, periódicos e papel destinado à sua impressão, nada mais é que forma de viabilização de outros direitos e garantias fundamentais expressos em seu art. $5^{\circ}$, como a livre manifestação do pensamento, a livre manifestação da atividade intelectual, artística, científica e de comunicação, independente de censura ou licença (incisos IV e IX), art. 206, II (a liberdade de aprender, ensinar, pesquisar e divulgar o pensamento, a arte e o saber), art. $220, \S \S 1^{\circ}$ e $6^{\circ}$, (a proibição da criação de embaraço, por lei, à plena liberdade de informação jornalística em qualquer veículo de comunicação social e inexistência de licença de autoridade para a publicação de veículo impresso de comunicação), dentre outros. (destacado)

Desta feita, visualiza-se que tal imunidade deve ser entendida, consoante Machado (1993), em seu sentido finalístico. Acrescenta, ademais, o doutrinador que seria frustrado o objetivo da norma caso fosse tributado quaisquer dos meios indispensáveis à produção dos livros, jornais e periódicos.

No âmbito do STF, visualiza-se que a temática é alvo de profundas discussões. De todo modo, podem ser destacados alguns pontos convergentes no que se refere à teleologia normativa: evitar embaraços ao exercício da liberdade de expressão intelectual, artística, cientifica e de comunicação; disseminar o conhecimento e propagar a difusão da cultura.

Nesse sentido, foi o voto prolatado pela Ministra Ellen Gracie, cujo trecho está transcrito a seguir:

A imunidade tributária sobre livros, jornais e periódicos e o papel destinado a sua impressão tem por escopo evitar embaraços ao exercício da liberdade de expressão intelectual, artística, cientifica e de comunicação, bem como facilitar o acesso da população a cultura, a informação e a educação. O Constituinte, ao instituir esta benesse, não fez ressalvas quanto ao valor artístico ou didático, à relevância das informações divulgadas ou à qualidade cultural de uma publicação. Não cabe ao aplicador da norma constitucional em tela afastar este beneficio fiscal instituido para proteger direito tão importante ao exercício da democracia, por força de um juízo 
subjetivo acerca da qualidade cultural ou do valor pedagógico de uma publicação destinada ao público infanto-juvenil. (SUPREMO TRIBUNAL FEDERAL, RE 221.239, Rel. Min. Ellen Gracie, julgamento em 25.05.2004, $2^{\mathrm{a}}$ Turma, DJ de 06.08.2004). (destacado)

Na mesma linha, é o acórdão relatado pelo Ministro Marco Aurélio:

A razão de ser da imunidade prevista no texto constitucional, e nada surge sem uma causa, uma razão suficiente, uma necessidade, está no interesse da sociedade em ver afastados procedimentos, ainda que normatizados, capazes de inibir a produção material e intelectual de livros, jornais e periódicos. (SUPREMO TRIBUNAL FEDERAL, RE 174.476, Rel. Min. Marco Aurélio, julgamento em 26.09.1996, Plenário, DJ de 12.12.1997). (destacado)

É inconteste, dessa forma, que esses meios de comunicação passam a ter configurações bastante diferentes daquelas usuais e sofrem constantes modificações. Trata-se de conceitos jurídicos cujo preenchimento do seu conteúdo deve ser feito pelo intérprete de acordo com as situações específicas da sociedade na qual está inserida.

Com tudo isso, há que se estabelecer que a imunidade dos livros deve ser a mais ampla possível, capaz de albergar não apenas um eventual conceito restritivo das obras impressas, mas todos os direitos amplamente enunciados no artigo $5^{\circ}$ da $\mathrm{CF} / 88$ e que têm relação com a livre manifestação do pensamento, a livre manifestação da atividade intelectual, o desenvolvimento humano pela educação, dentre outros.

\section{O Conceito Jurídico de Livro a partir do Neoconstitucionalis- mo e do Pós-Positivismo}

Neste momento, passa-se a discutir o atual contexto do neoconstitucionalismo e do pós-positivismo para então perceber a importância da Hermenêutica Constitucional na efetivação dos direitos e garantias fundamentais, em especial, no que se refere à imunidade tributária dos livros como garantia do contribuinte. 
Importa destacar que existem vários direitos fundamentais envolvidos na temática da imunidade dos livros eletrônicos, mas se optou por efetuar um corte epistemológico sob a perspectiva dos direitos ao meio ambiente ecologicamente equilibrado, à cultura e à liberdade de expressão.

\subsection{Um Olhar em Torno do Neoconstitucionalismo e do Pós-Positivis- mo: a importância do intérprete constitucional}

A superação histórica do jusnaturalismo demonstra que o Direito não tem como se justificar por fundamentos abstratos e metafísicos de uma razão subjetiva. Por outro lado, a crise do positivismo jurídico ensina que há um longo caminho entre Direito e norma jurídica e que a ética e moral, próprias de uma sociedade em constante transformação, não têm como permanecer distantes da ciência jurídica. Nenhum dos dois movimentos consegue mais atender de forma satisfatória às demandas sociais.

Inaugura-se, por conseguinte, um novo período intitulado de pós-positivista, onde ocorre a superação dialética da antítese entre positivismo e jusnaturalismo, com a distinção das normas jurídicas em regras e princípios, tendo como conteúdo os valores. Além da normatividade alcançada pelos princípios, percebe-se que os valores fazem parte das ciências sociais e, por consequência, do Direito, amadurecendo a tridimensionalidade de Miguel Reale (BARROSO, 2009).

No pós-positivismo, há uma abertura à dialética, trazendo os valores para as argumentações existentes, fortalecendo os princípios e proporcionando a efetivação da justiça material. Por isso, torna-se indispensável à superação do positivismo legalista e do jusnaturalismo. Os estudos hoje, porém, são voltados para tratar das diferenças entre regras e princípios.

O neoconstitucionalismo demanda construção teórica que faça a devida adaptação dos institutos jurídicos aos padrões firmados pela Constituição ao fixar novos cânones de interpretação para as normas infraconstitucionais (DUARTE; POZZOLO, 2010).

Não há dúvida de que a atividade de julgar passa a ter uma importância maior no pós-positivismo, na medida em que o Direito não se limita às regras jurídicas. O juiz não pode agir apenas por meio de raciocínios 
dedutivos, na lógica dos silogismos, como perdurou no positivismo. Com o retorno da Ética e da Moral ao Direito, o magistrado tem uma maior liberdade para proferir suas decisões.

Tal fato decorre da normatização dos princípios e do papel que os valores passaram a exercer na ciência jurídica. Os princípios não precisam estar positivados de forma expressa na ordem jurídica para ter validade. Em verdade, os princípios jurídicos encontram guarida na expressão “princípios gerais do Direito", previstos na Lei de Introdução ao Código Civil. ${ }^{7}$ Mas o legislador, sabiamente, não os enumerou de forma taxativa, na medida em que não há possibilidade de se engessar a sociedade.

Como se vê, não há como o rol dos princípios ser exaustivo e limitado, pois eles sinalizam os valores e os anseios da sociedade, que estão em constante transformação. Por conseguinte, limitá-los à ordem jurídica positiva é impossível, pois não se tem como congelar a dinâmica social.

Os princípios nascem de um movimento jurídico de indução, ou seja, do individual para o geral, emanando a justiça. A doutrina e, em especial, a jurisprudência realizam referido processo de abstração na teorização e aplicação do Direito. Vê-se que, neste momento, eles já são normas jurídicas, condensando valores e orientando o intérprete, uma vez que o Direito não só a lei, como queria o positivismo jurídico. Com a sua reiterada aplicação e permanência no seio social, o legislador, a fim de lhe garantir também segurança jurídica, ampara-o em uma lei, ou na própria Constituição, por meio de um raciocínio jurídico por dedução (BELCHIOR, 2011).

A norma, como se vê, traz uma estrutura lógica, cognoscente da conduta, estando, assim, formalizada. Por conta disso, a lógica jurídica não tem como deixar de ser formal exatamente pelo fato de suas estruturas serem aptas a acolher o objeto jurídico, que é uma espécie de objeto deôntico (normativo).

$7 \mathrm{O}$ artigo $4^{\circ}$, do Decreto-Lei n. 4.657/42, que introduziu a Lei de Introdução ao Código Civil no ordenamento jurídico brasileiro, dispõe que "Quando a lei for omissa, o juiz decidirá o caso de acordo com a analogia, os costumes e os princípios gerais de direito". 
Os raciocínios jurídicos, no entanto, são acompanhados por incessantes controvérsias, buscando uma decisão justa e com aceitabilidade social. Tal fato, segundo Perelman (2004, p. 13), é o bastante para

[...] salientar a insuficiência, no direito, de um raciocínio puramente formal que se contentaria em controlar a correção das inferências, sem fazer um juízo de valor da conclusão.

Em outras palavras, pode-se dizer que o Direito pretende atender aos anseios da sociedade, permitindo uma convivência pacífica entre os homens. Seu conteúdo, por conseguinte, é dinâmico, estando em constante transformação, devendo o mesmo ocorrer com o sentido captado pela norma, sob pena de uma estagnação. É exatamente nesse conteúdo que se visualiza a forma do ser, da prática, do concreto, do que efetivamente ocorre na realidade, o que nem sempre corresponde ao que está previsto na forma deôntica.

Logo, na formalização da norma, ocorrente pela sua estrutura deôntica, não há como abranger todo o conteúdo do Direito. Principalmente quando se verifica, durante a evolução histórica, que o Direito vai muito além daquilo que está explicitado na norma. Direito é mais do que lei, mais do que regra, mais do que norma.

Notadamente, o intérprete não pode ficar adstrito à norma, olvidando o grande mundo que é o sistema jurídico. A norma pretende trazer a segurança, mas isso não implica o alcance da justiça. Esta segurança é garantida pela forma deôntica, que cuida da estrutura da norma, impondo um "dever-ser". Aqui, percebe-se claramente que o movimento do pensamento é o dedutivo, partindo do geral (norma) para o individual (regular as relações jurídicas), cuidando os argumentos do ponto de vista da sua correção formal.

A relação entre segurança jurídica e justiça, dedução e indução, é clássica, haja vista que "[...] em todo sistema jurídico coexistem dois valores ético-sociais: a justiça e a segurança.” (SOUZA, 1987, p. 19). O Direito deve se adequar à sociedade (por meio da indução em prol da justiça), assim como a sociedade deve ser conformar ao Direito (realiza- 
do pela dedução, garantindo a segurança jurídica). Trata-se do equilíbrio clássico que deve ocorrer no Estado Democrático de Direito.

Nesse passo, a problemática da imunidade dos livros eletrônicos deve ser analisada sob o atual do contexto do pós-positivismo e da Hermenêutica Constitucional, o que impõe um incessante desafio do intérprete na aplicação das normas de direitos fundamentais, mais especificamente, das garantias fundamentais do contribuinte.

\subsection{O Direito Fundamental ao Meio Ambiente Ecologicamente Equili- brado}

A sociedade de risco, oriunda da pós-modernidade (BAUMAN, 2001), demanda transformações no Estado e no Direito de forma a minimizar os impactos da crise ambiental e controlar as dimensões do risco. Estado e Direito caminham juntos, um complementando o outro, com o objetivo de pacificação social. O Direito é, pois, discurso que legitima o papel do Estado. Parece que no atual contexto do risco, vinculado diretamente à problemática ambiental, urge modificações teóricas e funcionais no âmbito do Direito e do Estado.

Se lidar com o risco certo e em potencial, utilizando a expressão de Beck (1998), já era difícil no paradigma anterior, imagina gerir riscos imprevisíveis, em abstrato, em virtude das incertezas científicas. Nessa linha, urge a criação de uma nova gestão preventiva, por meio da utilização instrumentos preventivos e precaucionais, para lidar com toda a complexidade ambiental que paira pela sociedade hodierna.

Diante de tal consideração, parece oportuno assinalar que a Constituição Federal de 1988 foi o primeiro dos diplomas constitucionais brasileiros a versar deliberadamente sobre o meio ambiente, dispensando à matéria um tratamento amplo e diferenciado. A partir de um capítulo especificamente dedicado ao tema, o constituinte definiu o que viria a se tornar o núcleo normativo do direito ambiental brasileiro.

A proteção constitucional do meio ambiente, entretanto, é mais extensa, abrangendo uma série de outros dispositivos que, direta ou indiretamente, se relacionam a valores ambientais de forma holística e sistêmi- 
ca. Nessa linha, ilustra Benjamin (2008) que o capítulo que versa sobre o meio ambiente nada mais é do que o ápice ou a face mais visível de um regime constitucional que se dedica de forma difusa à gestão dos recursos ambientais.

A crise ambiental não ocorre de formada isolada, o que leva a constatar que a dignidade da pessoa humana não pode ser vista tão-somente no indivíduo, mas também em uma dimensão coletiva em sentido geral. Por conseguinte, traz à baila direitos que perpassam a esfera privada e se subordinam a interesses da maioria em prol do bem-estar social, em virtude da titularidade ser indefinida ou indeterminável. Assim, o princípio da solidariedade surge como instrumento que obriga que referidos direitos devam ser garantidos às gerações futuras, assumindo a dimensão intergeracional.

O meio ambiente sadio é condição para a vida em geral. E para que ocorra o equilíbrio ecológico, é necessário um esforço conjunto, de todas as esferas do corpo social, assim como do Poder Público, com o intuito de formar uma união de forças multilaterais no sentido de minimizar os impactos ambientais.

A Constituição Federal de 1988 trata do princípio da solidariedade como objetivo da República em seu artigo 3, I, ao prever a "[...] construção de uma sociedade livre, justa e solidária". No inciso IV do mesmo artigo, visualiza-se outro objetivo que comprova a preocupação do constituinte originário com a solidariedade, ao estabelecer a “[...] erradicação da pobreza e da marginalização social e a redução das desigualdades sociais e regionais". Como se vê, os dispositivos estabelecem um novo marco normativo-constitucional, ao consolidar a solidariedade como princípio da Lei Maior.

Ainda no texto constitucional, o artigo 225, núcleo do ambientalismo pátrio, cuida da solidariedade ao impor ao Poder Público e à coletividade o dever de proteger o meio ambiente para as presentes e as futuras gerações. Não há duvida de que o dever fundamental está diretamente relacionado ao princípio da solidariedade por dividir os encargos e responsabilidades na equidade geracional. 
O STF trata do dever de solidariedade oriundo do direito fundamental ao meio ambiente, em julgamento clássico, vinculando que referido princípio tem alcance para as presentes e futuras gerações:

[...] Todos têm direito ao meio ambiente ecologicamente equilibrado. Trata-se de um típico direito de terceira geração (ou de novíssima dimensão), que assiste a todo o gênero humano (RTJ 158/205-206). Incumbe, ao Estado e à própria coletividade, a especial obrigação de defender e preservar, em benefício das presentes e futuras gerações, esse direito de titularidade coletiva e de caráter transindividual (RTJ 164/158-161). O adimplemento desse encargo, que é irrenunciável, representa a garantia de que não se instaurarão, no seio da coletividade, os graves conflitos intergeneracionais marcados pelo desrespeito ao dever de solidariedade, que a todos se impõe, na proteção desse bem essencial de uso comum das pessoas em geral. [...] (Destacado) (BRASIL. Supremo Tribunal Federal - STF /MS 22164/SP. Relator Ministro Celso de Mello.

Diário de Justiça, 17 nov. 1995, p. 39.206).

O princípio da solidariedade aparece com um dos grandes desafios aos juristas por conta da teoria do risco, na medida em que demanda relacionamento entre as diversas gerações, o que torna a temática complexa, pois não se sabe o que estar por vir. Ilustra Benjamin (2009, p. 59) que só cabe fazer algumas conjecturas sobre

[...] a) quem habitará o planeta num futuro muito além dos dias de hoje; b) as conseqüências remotas que nossas ações atuais provocarão nesses habitantes incertos; e, c) os tipos de preferência adotados por tais gerações.

Dessa feita, o Sistema Tributário Nacional merece ser rediscutido para buscar a sustentabilidade, o que faz os estudiosos invocarem a Tributação Ambiental. O Estado, por meio do seu poder de tributar, precisa induzir comportamentos ecologicamente corretos, cuja extrafiscalidade exerce uma tarefa imprescindível.

Ao trazer a questão para a temática específica deste estudo, merece reflexão a extensão da imunidade dos livros para a sua forma eletrônica, 
no sentido de verificar se tal situação jurídica contribuiria ou não para a proteção do meio ambiente ecologicamente equilibrado, controlando, assim, os efeitos da sociedade de risco. Pergunta-se: o livro eletrônico contribui para minimizar os impactos negativos no meio ambiente?

\subsection{O Direito Fundamental à Cultura}

No que concerne à cultura, vislumbra-se que existe tanto uma dimensão cultural do bem ambiental como um direito fundamental à cultura. De uma forma bem objetiva, cultura é toda modificação que o homem faz na natureza com algum propósito. Mas quando se trata de um meio ambiente cultural, sua definição é diferenciada (SEGUIN, 2006).

Mister perceber a grandeza do conceito de ambiente cultural, o que implica em uma proteção jurídica ampla. O estabelecimento dos vínculos com as diferentes fases culturais relacionadas com as gerações humanas faz nascer um patrimônio cultural.

Interessante destacar, consoante Barros (2008), que diferentemente do meio ambiente natural que é (ser), ou seja, sua ontologia não necessita de qualquer tipo de intervenção do Estado para tanto, o ambiente cultural para adquirir referido status necessita de declaração do Poder Público. Assim, o meio ambiente cultural deve ser.

Acerca da concepção cultural dos bens ambientais, Silva (2009, p. 23) ressalta sua importância de refletir o sentido do humano, seu valor coletivo e a visão unitária do ambiente em todos os seus aspectos. No entanto, adverte o autor "[...] o risco de perdermos o sentido da Natureza como natura, o risco de cairmos em um ambientalismo abstrato, formal [...]" (BARROS, 2008, p. 25). Por conta disso, a natureza, com suas leis estáveis, há de ser considerada como uma importante referência, ou seja, um ponto de partida.

É importante observar a dimensão pluralista que deve ser dada ao meio ambiente cultural, haja vista que cada grupo social tem realidades distintas, devendo tal fato ser considerado tanto pelo legislador, ao elaborar as normas infraconstitucionais, quando pelo aplicador, pois se deve respeitar à autonomia dos padrões culturais locais, quando se tratar, em 
especial, das disposições constitucionais do artigo 225 que tratam de caça, pesca e fauna. (CASTILHO, 2009).

Dentro do ambiente cultural, destaca-se o meio ambiente intelectual, que tem como produto a propriedade intelectual no que concerne à parte de criação. Essa interface entre meio ambiente e propriedade intelectual é de suma importância para a própria hermenêutica dos bens intelectuais (WACHOWICZ, 2004).

À luz do ordenamento jurídico brasileiro, visualiza-se que o meio ambiente cultural está protegido pelo artigo 215, da Lei Maior, que aumentou o âmbito de abrangência do conceito de cultura e os mecanismos de sua proteção, incluindo, entre estes, a participação popular, -

[...] o Estado garantirá a todos o pleno exercício dos direitos culturais e acesso às fontes da cultura nacional, e apoiará e incentivará a valorização e a difusão das manifestações culturais [...]

- assim como pelo artigo 216 da Constituição Federal, segundo o qual o meio ambiente cultural é constituído pelo patrimônio artístico, histórico, turístico, paisagístico e arqueológico, espeleológico e cultural, ao englobar os bens de natureza material e imaterial, tomados individualmente ou em conjunto, portadores de referência à identidade, à ação, à memória dos diferentes grupos formadores da sociedade brasileira.

Para Fiorillo (2007, p. 73), o meio ambiente cultural

[...] traduz a história de um povo, a sua formação, cultura e, portanto, os próprios elementos identificadores de sua cidadania, que constitui princípio fundamental norteador da República Federativa do Brasil.

Destarte, ao analisar a teleologia da imunidade dos livros, percebe-se que a vontade do constituinte é propagar a cultura, a partir do acesso ao conhecimento em suas mais variadas formas. Nesse ponto, cabe discutir se referido dispositivo deve ser interpretado restritivamente, alcançando tão apenas o livro impresso. Questiona-se: o livro eletrônico dissemina a cultura e permite o conhecimento pela sociedade? 


\subsection{O Direito Fundamental à Liberdade de Expressão}

A liberdade de expressão se revela como uma característica das atuais sociedades democráticas. Referido direito é encontrado em vários instrumentos internacionais, tais como a Declaração dos Direitos Humanos de 1948, aprovada pela ONU; o Convênio Europeu para a proteção dos Direitos Humanos e das Liberdades Fundamentais, aprovado em Roma no ano de 1950; e, ainda, a Convenção Americana de Direitos Humanos (Pacto de San José da Costa Rica).

A Constituição Federal de 1988 estabelece, em seu artigo $5^{\circ}$, inciso IV, que "[...] é livre a manifestação do pensamento, sendo vedado o anonimato [...]", bem como traz, em seu inciso IX, que "[...] é livre a expressão da atividade intelectual, artística, científica e de comunicação, independentemente de censura ou licença”.

Ainda no texto constitucional, aponta-se o artigo 220, cujo caput dispõe que

[...] a manifestação do pensamento, a criação, a expressão e a informação, sob qualquer forma, processo ou veículo não sofrerão qualquer restrição, observado o disposto nesta Constituição.

Como se vê, o constituinte foi enfático sobre a necessidade de se preservar a livre circulação de ideias, mormente devido aos traumas causados pelo regime militar, quando da adoção da censura de forma banalizada (MARMELSTEIN, 2008, p. 105).

Sobre o tema, o STF já se manifestou nos seguintes termos:

A Constituição da Republica revelou hostilidade extrema a quaisquer práticas estatais tendentes a restringir ou reprimir o legítimo exercício da liberdade de expressão e de comunicação de idéias e de pensamento.

Essa repulsa constitucional bem traduziu o compromisso da Assembléia Nacional Constituinte de dar expansão às liberdades do pensamento. Estas são expressivas prerrogativas constitucionais cujo integral e efetivo respeito, pelo Estado, qualifica-se como pressu- 
posto essencial e necessário a pratica do regime democrático. A livre expressão e manifestação de idéias, pensamento e convicções não pode e não deve ser impedida pelo Poder Público nem submetida a ilícitas interferências do Estado. (SUPREMO TRIBUNAL FEDERAL, Pet. 3486/DF, rel. Min. Celso de Mello, j. 22/06/2006). (destacado)

Destarte, verifica-se que o constituinte não apontou quais os instrumentos poderiam ser utilizados para a efetivação do direito fundamental à liberdade de expressão, podendo-se concluir que a melhor interpretação é a mais ampla possível, haja vista que a intenção do legislador constitucional é propagar a comunicação de ideias e de pensamento, independente do veículo para tanto.

Logo, ao adequar a temática ao foco deste artigo, indaga-se: o livro em meio eletrônico permite a liberdade de expressão de seus autores e a disseminação de ideias e de pensamento?

\subsection{Em Busca de um Conceito Jurídico de Livro}

Inicialmente, saber o real alcance da palavra "livro" é fundamental para a análise que aqui se pretende. Entretanto, buscar esse conceito não é simples, pois

[...] ao conceituar uma palavra, devemos extrair dos signos que formam seu enunciado a essência capaz de criar em nossa mente uma significação que nos remeta ao objeto cujo conjunto de signos se refere. (WANDERLEY, 2010, p. 164)

Os próprios enunciados, já trabalhados por Carvalho, correspondem a um

[...] produto da atividade psicofísica de enunciação. Apresenta-se como conjunto de fonemas e grafemas que, obedecendo a regras gramaticais de determinado idioma, consubstancia a mensagem expedida pelo sujeito emissor. (CARVALHO, 2007, p. 22) 
Com o devido cuidado, a fim de não empobrecer este artigo científico, faz-se necessário indicar, pelo menos, um conceito expresso em um dicionário da língua portuguesa, evitando-se a utilização dos meios eletrônicos, para que não se venha taxar a escolha de parcial. Assim, no Dicionário Aurélio (1986, p. 1.042) lê-se:

Livro [Do lat. libru.] S.m. 1. Reunião de folhas ou cadernos, soltos, cosidos ou por qualquer outra forma presos por um dos lados, e enfeixados ou montados em capa flexível ou rígida. 2. Obra literária, científica ou artística que compõe, em regra, um volume. [...] 3. Seção do texto de uma obra, contida num tomo e que pode estar dividida em partes: [...] 4. Registro para certos tipos de anotações [...] (destacado no original)

Entretanto, fica evidente que o conceito contido no dicionário reflete apenas a ideia tradicional, até porque fugir desse entendimento pode representar um risco para aquele que tenta conceituar, especialmente no tocante aos livros, já que não há como se dar uma definição precisa, perfeita e acabada.

Dentro da ciência do Direito, percebe-se que o enunciado das normas jurídicas tanto pode dar margem a conceitos determinados quanto a indeterminados e isso acontece porque, segundo Moraes (1999, p. 56),

[...] as mesmas dificuldades de compreensão das palavras e expressões usadas no dia-a-dia transportam-se para o domínio da interpretação e aplicação das normas jurídicas.

Enfatiza a autora, ainda, que:

O conceito indeterminado pode abrigar uma série de situações hipotéticas. É possível identificar as situações concretas - os fatos que com certeza se enquadram no conceito. Também é possível identificar as situações concretas que com certeza não se amoldam ao enunciado. Entretanto, remanesce uma série de situações duvidosas, nas quais não há certeza se ajustam à hipótese abstrata. (MORAES, 1999, p. 58) 
Conceitos jurídicos indeterminados são termos ou expressões, dentro de normas jurídicas, que permitem que o intérprete ou aplicador, pelo fato de não terem exatidão em seu sentido, possam atribuir certo significado, mutável em razão da valoração que se proceda diante dos pressupostos da norma (CARVALHO FILHO, 2006, p. 43).

Assim, é preciso ir além desse atrelamento tradicional à palavra, na medida em que o livro é um conceito jurídico indeterminado, possuindo uma pequena margem cinzenta que será preenchida pelo intérprete no caso concreto. Não se devem engessar conceitos, sob pena de prejudicar o caráter evolutivo do próprio Direito, até porque a sociedade está em constante transformação. Por mais que muitas normas permaneçam inalteradas, o que deve ser modificado é a sua interpretação, cujo sentido deve ser captado a partir das circunstâncias especificas do caso concreto.

Deve-se partir da premissa de que o sentido, como ensina Falcão (2010), é inesgotável, motivo pelo qual o objeto poderá assumir várias formas, a depender do intérprete e da sua concepção acerca dos sentidos.

Logo, na medida em que a crise ambiental que ora se enfrenta se torna cada vez mais alarmante e que os meios tecnológicos permitem o acesso amplo à cultura, ao conhecimento e à propagação de ideias, faz-se necessário que o intérprete preencha a moldura do conceito de "livro" de tal forma que possa se adequar à nova realidade, que não é a mesma de outubro de 1988.

Um instrumento que necessariamente deve auxiliar o interprete neste intento é o próprio ordenamento jurídico, cuja aplicação se faz dedutivamente. Deve-se buscar, na ordem jurídica vigente, se existe alguma definição legal ou outras premissas vinculativas acerca da temática em discussão. Dessa forma, verifica-se que o conceito de livro foi trazido pela Lei n. 10.753, de 30 de outubro de 2003, que institui a Política Nacional do Livro. No artigo $2^{\circ}$ deste diploma encontra-se a seguinte definição:

Art. $2^{\circ}$ Considera-se livro, para efeitos desta Lei, a publicação de textos escritos em fichas ou folhas, não periódica, grampeada, colada ou costurada, em volume cartonado, encadernado ou em brochura, em capas avulsas, em qualquer formato e acabamento. 
Parágrafo único. São equiparados a livro:

I - fascículos, publicações de qualquer natureza que representem parte de livro;

II - materiais avulsos relacionados com o livro, impressos em papel ou em material similar;

III - roteiros de leitura para controle e estudo de literatura ou de obras didáticas;

IV - álbuns para colorir, pintar, recortar ou armar;

V - atlas geográficos, históricos, anatômicos, mapas e cartogramas;

VI - textos derivados de livro ou originais, produzidos por editores, mediante contrato de edição celebrado com o autor, com a utilização de qualquer suporte;

VII - livros em meio digital, magnético e ótico, para uso exclusivo de pessoas com deficiência visual;

VIII - livros impressos no Sistema Braille. (destacado)

O que se vê, no caput deste artigo, é a definição tradicional, conforme já encontrada nos dicionários clássicos de língua portuguesa. Entretanto, no parágrafo único, por equiparação, vê-se a figura do livro eletrônico, com uma ressalva altamente questionável de que a mesma só ocorrerá se o uso do livro for exclusivo para pessoas com deficiência visual.

Referido dispositivo é curioso e passível de discussão, na medida em que um livro em meio digital de uso exclusivo de pessoas com deficiência digital é considerado livro enquanto que o mesmo recurso pode não ser assim equiparado, caso venha a ser utilizado por quem não possui a deficiência.

Em verdade, trata-se de uma profunda confusão relacionada ao termo, uma imprecisão que ronda os meandros da língua portuguesa e as próprias definições legais. Até porque o legislador é explícito ao asseverar que o conceito de livro deve ser aplicado tão-somente em relação à lei em tela ("para efeitos desta lei"), qual seja, a que instituiu a Política Nacional do Livro.

Por outro lado, não parece lógico nem razoável, rememorando Siches (1973), a utilização por analogia do conceito de livro supracitado 
para o eletrônico, pois limita e condiciona o acesso dos meios eletrônicos tão-somente aos portadores de deficiência visual.

A partir dessa guinada proporcionada pela tecnologia, bem como de outras mudanças estruturais por que passa a sociedade, deve ser do interesse da doutrina e da jurisprudência aclarar a verdadeira intenção do constituinte ao instituir tal imunidade. Isso porque, com os novos meios de informática e com a crise ambiental, fortalecida pela sociedade de risco, conceitos estanques e bem definidos, como os de "livros, jornais e periódicos", passam a sofrer sérios abalos e novos moldes.

Assim, entende-se que o conceito jurídico de livro deve ser o mais amplo possível, tendo em mente uma interpretação teleológica e sistemática que busque captar um sentido conveniente com as características da sociedade hodierna. Aqui, deve-se aplicar não apenas o raciocínio jurídico dedutivo, mas principalmente o indutivo, o que torna legítima e necessária uma mutação constitucional do artigo 150, inciso IV, alínea "d", da Carta Magna.

\section{Desafios e Perspectivas do STF Frente à Temática da Imuni- dade dos Livros Eletrônicos}

A interpretação e a aplicação do alcance das imunidades tributárias, principalmente no que concerne aos livros e seus acessórios, sempre foi alvo de muita discussão na jurisprudência do STF. Por esse motivo, foi editada a Súmula 657, que assim dispõe: "A imunidade prevista no art. $150, \mathrm{VI}, \mathrm{d}$, da CF abrange os filmes e papéis fotográficos necessários à publicação de jornais e periódicos".

Sobre o tema, destacam-se os seguintes julgados:

1. Recurso extraordinário inadmitido. 2. Imunidade tributária. Art. 150, VI, d, da Constituição Federal. 3. A jurisprudência da Corte é no sentido de que apenas os materiais relacionados com o papel estão abrangidos por essa imunidade tributária. 4. Agravo regimental a que se nega provimento. (SUPREMO TRIBUNAL FEDERAL, 
AI 307.932/SP-AgR, Segunda Turma, Rel. Min. Néri da Silveira, DJ 31/08/2001).

Tributário. Imunidade conferida pelo art. 150, IV, "d", da Constituição. Impossibilidade de ser estendida a outros insumos não compreendidos no significado da expressão "papel destinado à sua impressão". Precedentes do Tribunal. [...] Agravos regimentais desprovidos. (SUPREMO TRIBUNAL FEDERAL. RE 324.600/SP-AgR, Primeira Turma, Rel. Min. Ellen Gracie, DJ 25/10/2002.)

[...] A orientação firmada por esta Corte interpreta o art. 150, IV, d, da Constituição de forma a restringir a salvaguarda constitucional aos estritos contornos dos objetos protegidos: livros, jornais, periódicos e o papel destinado a sua impressão. [...] Dado que o suporte físico que funciona como mídia ("cd-room") não se confunde e não pode ser assimilado ao papel, o acórdão recorrido contrariou a orientação fixada por esta Corte. [...] (SUPREMO TRIBUNAL FEDERAL. RE 416.579/RJ. Rel. Min. Joaquim Barbosa, julg. 17/12/2009, DJ 05/02/2010).

Recentemente, o Ministro Dias Toffoli manifestou entendimento quando do julgamento do RE 330.817/RJ, interposto pelo Estado do Rio de Janeiro, na direção de que:

[...] A irresignação merece prosperar, haja vista que a jurisprudência da Corte é no sentido de que a imunidade prevista no art. 150, inciso VI, alínea "d", da Constituição Federal, conferida a livros, jornais e periódicos, não abrange outros insumos que não os compreendidos na acepção da expressão "papel destinado a sua impressão". (SUPREMO TRIBUNAL FEDERAL. RE 330.817. Rel. Dias Toffoli. DJ 04/03/2010).

Sobre este processo, merece destacar a manifestação da Décima Primeira Câmara Cível do Tribunal de Justiça do Estado do Rio de Janeiro, órgão prolator do acórdão recorrido:

[...] Imunidade concernente ao ICMS. Art. 150, VI, “d”, da Constituição Federal. Comercialização da Enciclopédia Jurídica Eletrôni- 
ca por processamento de dados, com pertinência exclusiva ao seu conteúdo cultural - software.

Livros, jornais e periódicos são todos os impressos, os gravados, por quaisquer processos tecnológicos, que transmitem idéias, informações, comentários, narrações reais ou fictícias sobre todos os interesses humanos, por meio de caracteres alfabéticos ou por imagens e, ainda, por signos.

A limitação do poder de tributar encontra respaldo e inspiração no principio no Tax on Knowledgs.

Sentença que se mantém em duplo grau obrigatório de jurisdição. (TRIBUNAL DE JUSTIÇA DO ESTADO DO RIO DE JANEIRO. Décima Primeira Câmara Cível)

Nos autos deste Recurso Extraordinário, o parecer do Ministério Público Federal foi pelo seu desprovimento, ou seja, pela extensão da imunidade aos livros eletrônicos. Após o julgamento do Ministro Toffoli, a empresa ELFEZ EDIÇÃO COMÉRCIO E SERVIÇOS LTDA interpôs embargos de declaração da decisão, ocasião em que foi determinado o sobrestamento do feito, haja vista que foi reconhecida a repercussão geral da matéria, a partir do RE 595.676/RJ, de relatoria do Ministro Marco Aurélio, envolvendo o alcance da imunidade destinada aos livros, jornais e periódicos de que trata o artigo 150, inciso VI, alínea “d”, da Lei Maior.

Ao analisar os recentes julgamentos do STF, verifica-se que a Corte Constitucional vem interpretando os dispositivos constitucionais referentes à imunidade tributária dos livros de forma restritiva. O livro eletrônico, produzido via CD-ROM, é tratado como insumo à produção do livro impresso, não recebendo a citada proteção constitucional.

Entretanto, observando de forma detalhada os argumentos acima colacionados, integrantes de outros processos julgados pelo órgão de cúpula, percebe-se que o STF vem interpretação o referido dispositivo de forma equivocada.

Inicialmente, ao argumento de que a imunidade não deve ser estendida a outros insumos não compreendidos na expressão "papel destinado a sua impressão", não se verifica qualquer pertinência com os livros digi- 
tais. Isto porque, como se vê, o argumento apresentado só nega elastecimento da expressão contida na parte final do artigo 150, inciso VI, alínea "d", da Constituição.

Quando a CF/88 indica que a imunidade será dos "livros, jornais, periódicos e o papel destinado a sua impressão", não se quer incluir os livros digitais na parte final da alínea, mas justamente no próprio conceito de livro, ao início dele. É absurda, ilógica e desproporcional a tese de que livro eletrônico seria um insumo do livro impresso. Seu lugar é no próprio conceito jurídico de livro.

Parece que o verdadeiro interesse do STF está camuflado no receio da extensão da imunidade aos livros eletrônicos a ponto de sua imunidade vir a ameaçar a arrecadação dos impostos, o que geraria impactos econômicos e financeiros. Por outro lado, é inconteste a preocupação da Corte com o novo mercado com nítidos interesses empresariais, mas cujo produto mantém a mesma finalidade de disseminação da cultura e do conhecimento.

Além disso, ao verificar a jurisprudência da Corte, o que se vê é uma ausência de julgados que tratem matéria semelhante, até porque tais casos envolvendo livros eletrônicos agora é que começam a aflorar no seio do Tribunal Constitucional.

Assim, reconhecida a repercussão geral da questão constitucional contida no RE n. 595.676, que trata de questão da imunidade dos livros digitais, aguarda-se um julgamento coerente com as recentes modificações tecnológicas operadas em todo o mundo e que refletem um ser humano altamente integrado ao ambiente virtual.

\section{Conclusões}

A questão da imunidade dos livros eletrônicos deve ser analisada sob o atual do contexto do pós-positivismo e do neoconstitucionalismo, o que impõe uma desafiadora tarefa do intérprete na aplicação das normas de direitos fundamentais, mais especificamente, das garantias fundamentais do contribuinte. 
Não se deve engessar conceitos, sob pena de prejudicar o caráter evolutivo do próprio Direito, até porque a sociedade esta em constante transformação. Por mais que muitas normas permaneçam inalteradas, o que deve ser modificado é a sua interpretação, cujo sentido será captado de acordo com as características da sociedade hodierna.

Desta feita, na medida em que a crise ambiental que ora se enfrenta se torna cada vez mais alarmante e que os meios tecnológicos permitem o acesso amplo à cultura, ao conhecimento e à propagação de ideias, é mister que o intérprete preencha a moldura do conceito jurídico de "livro" de tal forma que possa se adequar à nova realidade, que não é a mesma de outubro de 1988.

O conceito jurídico de livro, portanto, deve ser o mais amplo possível, tendo em mente uma interpretação teleológica e sistemática, o que faz legitima e necessária uma mutação constitucional do artigo 150, inciso IV, alínea "d", da Carta Magna.

Conclui-se, ainda, que a extensão da imunidade aos livros eletrônicos contribui para a proteção do direito ao ambiente sadio, haja vista evitar a impressão de papel, colaborando para o ambiente virtual e para uma gestão preventiva do risco ambiental. Estimula, ainda, a propagação da cultura e da liberdade de expressão, pois a sociedade de informação permite um número cada vez maior de pessoas com acesso ao conhecimento por meio dos instrumentos digitais.

Ao analisar os recentes julgamentos do STF, verifica-se que a Corte Constitucional vem interpretando os dispositivos constitucionais referentes à imunidade tributária dos livros de forma restritiva e, por conseguinte, equivocada, pois o livro eletrônico não se confunde com insumo.

Portanto, aceitar esta tese que parece preponderar no STF é afirmar que a única forma de livro protegida pela imunidade é a impressa. É ir na contramão de toda a ordem jurídica constitucional, contextualizada pelo pós-positivismo. É retroceder ao Estado oitocentista meramente formal. É resgatar um positivismo jurídico duro, totalmente míope. É praticamente um "balde de água fria" em conquistas históricas dos direitos e garantias 
fundamentais e no âmago do que é justo. É desnaturar a dignidade da pessoa humana e, por conseguinte, o próprio Direito.

Por fim, espera-se um entendimento dessa Egrégia Corte favorável à cultura brasileira e ao acesso mais consciente ecologicamente aos meios de informação, sejam eles livros, jornais ou periódicos, fazendo uma leitura abrangente no tocante ao uso do meio eletrônico e coerente com os tempos pós-modernos.

\section{Referências}

BALEEIRO, Aliomar. Direito tributário brasileiro. 11. ed. rev. e compl. por Mizabel Derzi. Rio de Janeiro: Forense, 2007.

BARROS, Wellington Pacheco. Curso de direito ambiental. 2. ed. São Paulo: Atlas, 2008.

BARROSO, Luís Roberto. Fundamentos teóricos e filosóficos do novo direito constitucional brasileiro: pós-modernidade, teoria crítica e póspositivismo. Revista Diálogo Jurídico, Salvador, CAJ - Centro de Atualização Jurídica, v. 1, n. 6, setembro, p. 1-32, 2001. Disponível em: $<$ www.direitopublico.com.br>. Acesso em: 20 fev. 2009.

BAUMAN, Zygmunt. Modernidade líquida. Rio de Janeiro: Jorge Zahar, 2001.

BECK, Ulrich. La sociedad del riesgo: hacia una nueva modernidad. Barcelona: Paidós, 1998.

BELCHIOR, Germana Parente Neiva. Hermenêutica Jurídica Ambiental, São Paulo: Saraiva, 2011.

BENJAMIN, Antonio Herman. Constitucionalização do ambiente e ecologização da Constituição brasileira. In: LEITE, José Rubens Morato; CANOTILHO, José Joaquim Gomes (Org.). Direito constitucional ambiental brasileiro. 2. ed. São Paulo: Saraiva, 2008.

. A Natureza no Direito Brasileiro: coisa, sujeito ou nada disso. In: CARLIN, Volnei Ivo (Org.). Grandes temas de direito administrativo: homenagem ao Professor Paulo Henrique Blasi. Campinas, Millenium, 2009. 
CANOTILHO, José Joaquim Gomes. Direito constitucional e teoria da constituição. 3. ed. Coimbra: Almedina, 1999.

CARRAZZA, Roque Antonio. Curso de direito constitucional tributário. 24. ed. São Paulo: Malheiros, 2008.

CARVALHO, Paulo de Barros. Direito tributário: Fundamentos Jurídicos da Incidência. 5. ed. São Paulo: Saraiva, 2007.

CARVALHO FILHO, José dos Santos. Manual de direito administrativo. 15. ed. rev. ampl. e atual. Rio da Janeiro: Lumen Juris, 2006.

CASTILHO, Ela Wiecko V. de; CASTILHO, Manoel Lauro V. de. A diversidade cultural no conceito constitucional de meio ambiente. In: CARLIN, Volnei Ivo (Org.). Grandes temas de direito administrativo: homenagem ao Professor Paulo Henrique Blasi. Campinas: Millenium, 2009.

DUARTE, Écio Oto Ramos; POZZOLO; Suzanna.

Neoconstitucionalismo e positivismo jurídico: as faces da Teoria do Direito em tempos de interpretação moral da Constituição. 2. ed. São Paulo: Landy, 2010.

FALCÃO, Raimundo Bezerra. Hermenêutica. 2. ed. São Paulo: Malheiros, 2010.

FIORILLO, Celso Antônio Pacheco. Curso de direito ambiental brasileiro. 8. ed. rev. atual. e ampl. São Paulo, Saraiva, 2007.

HESSE, Konrad. A força normativa da constituição. Tradução de Gilmar Ferreira Mendes. Porto Alegre: Sergio Antonio Fabris Editor, 1991.

HOLANDA, Aurélio Buarque de. Novo dicionário Aurélio da Língua Portuguesa. 2. ed. rev. Rio de Janeiro: Nova Fronteira, 1986.

LIMA, Francisco Gérson Marques de. Fundamentos constitucionais do processo: sob a perspectiva da eficácia dos direitos e garantias fundamentais. São Paulo: Malheiros, 2002. 
MACHADO, Hugo de Brito. Curso de direito tributário. 8. ed. São Paulo: Malheiros, 1993.

MACHADO, Schubert de Farias. Imunidade do livro em CD-ROM. Revista Dialética de Direito Tributário, São Paulo, v. 78, p. 91-99, mar. 2002.

MARMELSTEIN, George. Curso de direitos fundamentais. São Paulo: Atlas: 2008.

MENDES, Gilmar Ferreira; COELHO, Inocêncio Mártires; BRANCO, Paulo Gustavo Gonet. Curso de direito constitucional. 4. ed. rev. e atual. São Paulo: Saraiva, 2009.

MORAES, Germana de Oliveira. Controle jurisdicional da administração pública. São Paulo: Dialética, 1999.

PERELMAN, Chaïm. Lógica jurídica: nova retórica. Tradução de Vergínia K. Pupi. São Paulo: Martins Fontes, 2004.

SARLET, Ingo Wolfgang. A eficácia dos direitos fundamentais. 9. ed. Porto Alegre: Livraria do Advogado, 2007.

SÉGUIN, Elida. Direito ambiental: nossa casa planetária. Rio de Janeiro: Forense, 2006.

SICHES, Luis Recaséns. Nueva filosofia de la interpretación del derecho. 2. ed. México: Porrúa, 1973.

SILVA, José Afonso da. Direito ambiental constitucional. 7. ed. São Paulo: Malheiros, 2009.

SOUZA, Carlos Aurélio Mota de. Poderes éticos do juiz. Porto Alegre: Fabris, 1987.

WACHOWICZ, Marcos. Propriedade intelectual do software \& revolução da tecnologia da informação. Curitiba: Juruá, 2004 WANDERLEY. Thiago Barbosa. A imunidade do livro face à sua evolução conceitual. Revista Dialética de Direito Tributário, São Paulo, v. 179, p. 161-170, ago. 2010. 